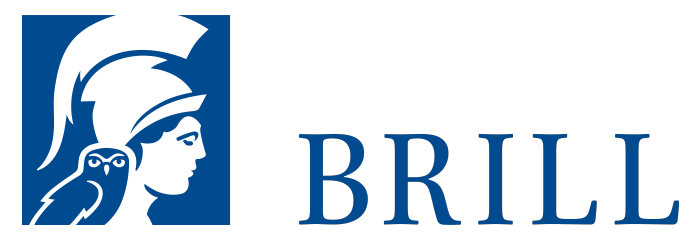

\title{
Petrarcas Rerum vulgarium fragmenta als Liederbuch (Conzoniere): Kompositionsprinzipien, Form und Sinn
}

\section{Author: Bernhard König}

Die Nordrhein-Westfälische Akademie der Wissenschaften und der Künste ist eine Vereinigung der führenden Forscherinnen und Forscher des Landes. Sie wurde 1970 als Nachfolgeeinrichtung der Arbeitsgemeinschaft für Forschung des Landes Nordrhein-Westfalen gegründet. Die Akademie ist in drei wissenschaftliche Klassen für Geisteswissenschaften, für Naturwissenschaften und Medizin sowie für Ingenieur- und Wirtschaftswissenschaften und in eine Klasse der Künste gegliedert.

Mit Publikationen zu den wissenschaftlichen Vorträgen in den Klassensitzungen, zu öffentlichen Veranstaltungen und Symposien will die Akademie die Fach- und allgemeine Öffentlichkeit über die Arbeiten der Akademie und ihrer Forschungsstellen informieren.

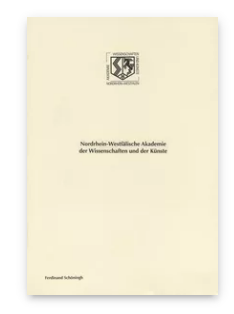

Pages: 33 Seiten

Language:

German

Subjects:

General,

Philosophy

Publisher: Brill |

Schöningh

Series:

Nordrhein-

Westfälische

Akademie der

Wissenschaften und

der Künste - Vorträge:

Geisteswissenschaften,

Volume: 414

E-Book (PDF)

Released online:

20 Jan 2020

ISBN: $978-3^{-}$

657-76477-8

List price

USD \$24.00

Paperback

Publication date:

21 Nov 2007

ISBN: 978-3-

506-76477-5

List price

USD \$24.00 
For more information see brill.com

Order information: Order online at brill.com +44330 333 0049 | customerservices@brill.com Submission information: brill.com/authors

Titles published by Brill | Fink, Brill | mentis or Brill | Schöningh: +49(o)715413279216| brill@brocom.de 